\title{
DOES EARNINGS MANAGEMENT EXERT PRESSURE ON FIRMS' RETURN ON ASSETS AND EQUITY? THE CASE OF SUB-SAHARAN AFRICA
}

\author{
Edesiri Godsday Okoro"* and Confidence Joel Ihenyen ${ }^{2}$ \\ ${ }^{1}$ Department of Accounting and Finance, Faculty of the Social Sciences, Delta State University, Nigeria \\ ${ }^{2}$ Department of Accounting/Finance, Faculty of Management Sciences, Niger Delta University, Nigeria
}

Regardless of the viewpoints of prior studies on earnings management, no study has been carried out on whether earnings management exerts pressure on firms return on assets and equity, particularly in SubSaharan Africa in a single study. Drawing inferences from the existing earnings management models, a dissimilar model of earnings management, unlike those used in prior studies, which may match the peculiarity of Sub-Saharan Africa is developed in this paper. The data used were obtained from the Stock Exchange database of Sub-Saharan African countries by employing the fixed and random effects statistical technique. Using the proposed earnings management model, the study finds the intriguing results that may contribute to knowledge and magnify the literature that, notwithstanding the fact that earnings management exerts significant pressure on firms' performances, it is even more so deemed as high in South Africa, only to be followed by West Africa, and low in East Africa. Interestingly, the study finds that the size of a firm plays a vital role in moderating the nexus between the earnings management and performances of Sub-Saharan African firms.

Keywords: earnings management, return on assets, return on equity, financial statements, Sub-Saharan Africa

\section{INTRODUCTION}

In the accountancy literature, there is robust empirical evidence on earnings management, with various phrases used to depict the concept such as income smoothing, accounting hocus-pocus,

* Correspondence to: E. G. Okoro, Department of Accounting and Finance, Faculty of the Social Sciences, Delta State University, Nigeria; e-mail: edesirioracle@yahoo.com aggressive accounting, engineering accounting, and creative accounting, among others. Conceivably, the widespread literature on earnings management may be associated with the varied usage of earnings management phrases together with cravings by firms to beat earnings management practices. Interestingly, the literature on earnings management is staggered by remarkable, but divergent results (Jones, 1991; Dechow, Sloan \& Sweeney, 1995; Zunera, 
Farah \& Muhammad, 2015; Gnyana, 2016; Cole, 2017; Grimaldi, 2019; Thenmozhi, Saravanan \& Sasidharan, 2019; Boghdady, 2019; Augustia, Muhammad \& Permatasari, 2020; Ali, Ismael \& Ahmed, 2020; Hunjra, Perveen, Chani \& Mehmood, 2020).

As R. E. Verrecchia (2009) sees it, earnings management infers the corporate entities assuming that the accounting measures of performance precisely replicate real performance, and do not assess the traits of accounting measures to assess whether that is actually the case. Alluding to the viewpoint expressed by R. E. Verrecchia (2009), earnings management denotes a seemingly magical process of transforming accounting figures into financial statements by management in order to disclose highquality earnings. For instance, using fair value in determining accounting figures provides the users of financial statements with better information compared to the historical cost. However, there is a standpoint that fair value accounting decreases income when values decrease, on the one hand, and increases income volatility when value increases. Impliedly, accounting choices and methods (e.g. fair value) by firms may not portray real performance, so that it may have a significant impact on the usefulness of financial statements for users.

F. Dobre, L. Brad and R. Ciobanu (2015) and R. B. Gnyana (2016) remark that, as opportunism is circumscribed by the accounting regulatory framework for the accounting choices and methods to circumvent earnings management practices, there is much recent evidence that firms engage themselves in negative earnings management practices in order to disclose superior performance. The views expressed by F. Dobre et al (2015) and R. B. Gnyana (2016) are corroborated by positive accounting thinkers, such as R. L. Hagerman and M. E. Zmijewski (1979) and R. L. Watts and J. L. Zimmerman (1986), who advocate numerous rationales why management engage themselves in earnings management.

Predominant among the rationales comprised the disclosure of a superior management bonus (Gaver, Gaver, \& Austin, 1995), tumbling the probability of the bond-covenant breach and contractual outcomes
(DeFond \& Jiambalvo, 1994; Ball \& Shivakumar, 2006; Barth, Landsman \& Lang, 2008) and slashing regulation and political scrutiny (Jones, 1991). More worrisome is how these may distort the stakeholders' perception of the underlying economic performance of the financial position of firms (Bartov, Gul \& Tsui, 2000; Kothari, Leone \& Wasley, 2005). Plausibly, there are two divides to earnings management, namely positive (which does not distort the underlying economic performance of firms) and negative (a repetition to avoid 'reporting red-ink') (Burgstahler \& Dichev, 1997; Barth, 2010; Cole, 2017; Grimaldi, 2019; Thenmozhi et al, 2019; Hunjra et al, 2020)

Worthy of note is the fact that, regardless of the viewpoint of prior studies on earnings management, there has been no study on whether earnings management will exert pressure on firms' return on assets and return on equity, particularly in SubSaharan Africa in a single study. Drawing inferences from the existing models for detecting the application of earnings management by J. Jones (1991) and P. M. Dechow et al (1995), a dissimilar model for detecting earnings management, unlike those used in prior studies, which may match the peculiarity of the firms in Sub-Saharan Africa, is developed in this paper.

Using the proposed models for detecting earnings management advocated in this study, more intriguing results that will contribute to knowledge and magnify the literature on earnings management are offered, which requires the empirical scrutiny that the study attempts to satisfy. Thus, secondary data as its scientific instrument and the ordinary least square and fixed and random effects in assessing whether earnings management exerts pressure on the two indicators of performance (namely return on assets and return on equity) in the selected nations of Sub-Saharan Africa (Western - Nigeria), (Southern South Africa) and (Eastern - Kenya) are used in the paper. The paper is structured as follows: Section 2 - Literature Review and Hypotheses Development, Section 3 - Theoretical Framework, Section 4 Data and Methods, Section 5 Results, Section 6 - Discussion and Section 7 - Conclusion. 


\section{LITERATURE REVIEW AND HYPOTHESES DEVELOPMENT}

\section{Return on Assets}

Undeniably, an entity's performance is predisposed to the level of earnings management by means of accrual accounting. Return on assets (ROA) is the fundamental performance metrics resulting from accrual accounting. Usually, ROA is estimated on the basis of net income divided by the total assets or the ratio of operating income to the total assets. These forms of estimations, however, have been broadly employed in the literature on earnings management (Kothari et al, 2005; Ayers, Jiang \& Yeung, 2006; Lennox \& Park, 2006; Gong, Li \& Xie, 2008; Moradzadehfard \& Nazari, 2013; Elshafie \& Nyadroh, 2014; Dobre et al, 2015; Cole, 2017).

G. Gong et al (2008) find a significant positive association between earnings management and ROA, suggesting that entities management seems to overextrapolate the past performance in forecasting future earnings. According to G. Gong et al (2008), high (low) earnings may result from superior (poor) ROA and the neutral application of accounting conventions and principles rather than the proactive choices made by the management with respect to the accounting methods striving to convey their personal judgment about the prospects the entity has. Besides, the majority of the studies on earnings management have included the performance metrics of ROA in their empirical models, claiming that ROA is one of the major performance metrics influenced by earnings management. Given the submission and empirical results of prior studies, ROA was included in our model. Hence, it was hypothesized as follows:

H1: Earnings management exerts no significant pressure on a firm's return on assets.

\section{Return on Equity}

Return on equity (ROE) is the reported performance that shareholders resort to when assessing how efficient management has performed over years.
From shareholders' point of view, particularly from the point of view of internal stakeholders, retained earnings are a better source of funds than outside financing. ROE is the measure of the performance of an entity and the same is estimated as the value of the net income returned as a percentage of the shareholders' equity (the ratio of the profit after tax to equity). ROE shows how much of a profit entities generate from each monetary unit invested by the shareholders.

ROE has not been deeply used in the literature on earnings management. However, there are but the few studies (Rangan, 1998; Teoh \& Wong, 1998; Boghdady, 2019) that have used these performance metrics. Moreover, prior studies find the evidence that earnings management significantly affects ROE. A study by S. Rangan (1998) and a study by M. A. Ali, H. R. Ismael and A. H. Ahmed (2020) find the evidence that equity-issuing entities on average tend to have greater positive accruals in the years surrounding the issue and these accruals can partially affect performance to such an extent that management are made to employ earnings management. Contrary to the results achieved by S. Rangan (1998), S. H. Teoh et al (1998) and A. B. A. Boghdady (2019) find the evidence that a negative association between accruals and ROE is more obvious for current accruals than for the total accruals. Based on these empirical results, ROE is included in our empirical model. Thus, the second hypothesis reads as follows:

H2: Earnings management does not exert significant pressure on a firm's return on equity.

\section{THEORETICAL FRAMEWORK}

In this paper, the theoretical underpinning is on the Theory of Accounting Discretion (TAD). TAD is a new theoretical archetype proposed by researchers, describing how management employ their Freedom of Choice (FOC) or Private Judgment (PJ) in adjusting entities' cashflows. When the adjustment of a firm's cashflow is concerned, the FOC or the PJ offer management diverse accounting treatments 
and management techniques aimed at reporting accounting figures in financial statements in such a way that they reflect high-quality earnings for the firm. The discretion used by the management of an organization is usually created in compliance with the International Financial Reporting Standards (IFRS), which permit management to employ the dissimilar choices of and methods for accounting judgments in adjusting cashflows. The discretions accorded by the IFRSs are the drivers of earnings management.

The underlying philosophy of TAD is that an entity's cashflows are adjusted based on a human judgment, a personal decision and a normative choice. Consequently, the characteristics of a firm, such as its size, management interests and ownership structure, as well as other characteristics, should be considered as the fundamental elements of earnings management. The characteristics of a firm accord management with flexible opportunities to experiment or transform accounting figures. More importantly, TAD is a normative accounting theory that describes the diverse accounting choices and methods used by management since it informs us about how management employs discretion in reporting theoretical performance rather than real performance. However, it totally deviates from the perspective of positive accounting theory, where the prime concern deals with accounting judgment aimed at disclosing real performance.

\section{DATA AND METHODS}

In this paper, an ex post facto design was adopted. The design was adopted since the study seeks to establish the variables connected with a certain occurrence by studying the past events of the existing condition. According to F. Nachmias and D. Nachmias (2009), the design supports the fact that the variables (e.g. earnings management, return on assets and return on equity) employed in an ex post facto study cannot be manipulated since the event already exist. The study population comprised all the publicly quoted consumer and industrial goods companies on the recognized Stock Exchanges of Sub-Saharan Africa
- Western (Nigeria), Southern (South Africa) and Eastern (Kenya).

In Nigeria, there are 41 publicly quoted consumer and industrial goods firms (Nigerian Stock Exchange, 2018), 23 in Kenya (Nairobi Securities Exchange, 2018) and 77 in South Africa (Johannesburg Stock Exchange, 2018), which makes a total of 141 publicly quoted consumer and industrial goods firms in the selected Sub-Saharan African countries.

A stratified random sampling technique was adopted. Sub-Saharan Africa was divided into the four regions: West Africa, South Africa, East Africa and Central Africa. All the regions of Sub-Saharan Africa are divided into the two strata (based on the robustness of the economy and the viability of the stock exchange), which results in the selection of the three regions/ countries of Sub-Saharan Africa (Western: Nigeria, Southern: South Africa and Eastern: Kenya). After having selected the countries based on the robustness of their economies and the viability of their stock exchanges, a judgmental sampling technique was employed.

The employed judgmental sampling was premised on certain yardsticks: first, the most capitalized firms in each selected Stock Exchange of Sub-Saharan Africa were selected; second, the firms with a wide-ranging dataset required for the study were included, while those with an incomplete dataset were excluded, notwithstanding the first yardstick. The judgmental sampling technique became imperative at this stage since the researcher had limited access to the relevant dataset of all the publicly quoted firms of Sub-Saharan Africa.

Given the above frameworks, a total of 29 firms were selected in Nigeria, 56 in South Africa, and 17 in Kenya, totaling 102 firms in the selected countries of Sub-Saharan Africa. With respect to the sampling techniques employed, Central Africa was excluded from the study sample. Hence South Africa was the highest with the sampled firms, only to be followed by Nigeria and, finally, Kenya.

The study data were obtained from a secondary source, more precisely from the Stock Exchange 
Fact Books, Annual Reports and Accounts and the Internet websites of the quoted firms operating in the Sub-Saharan African countries. The data comprised the performance measures comprising of Return on Equity (ROE), Return on Assets (ROA), and the earnings management components (net income, earnings before interest and taxes, cashflow from operations, the total assets and revenue) and the control measures (changes in the earnings before interest and taxes, a net profit after tax and the size of the firm). In the paper, a dissimilar model for predicting earnings management different from those employed in the existing studies and peculiar for SubSaharan Africa is proposed. Besides, the study drew inferences from the existing models for predicting earnings management proposed by J. Jones (1991) and P. M. Dechow et al (1995). Employing both models simultaneously, our earnings management model is given as follows:

$E M T=\frac{N I-C F O}{T A}+\frac{E B I T-C F O}{R E V}$

where EMT is Earnings management, TA stands for the total assets, and REV means revenue. NI is used for net income, CFO stands for cashflow from operations, EBIT means earnings before interest and taxes. The literature on earnings management suggests that income, expenses and assets should be considered as the most manipulated accounting figures (Gong et al, 2008; Moradzadehfard \& Nazari, 2013; Abdoli, Bakhtiarnezhad \& Bakshi, 2012; Elshafie \& Nyadroh, 2014; Cole, 2017).

The theoretical basis for the employed empirical model is premised on TAD. Said theoretical paradigm indicates that management may employ FOC when adjusting performance and cashflow, given the diverse accounting choices and methods availing them. J. Jones (1991) shows that a firm's management manipulates expenses/bad debts rather than revenue. Contrarily, P. M. Deschow et al (1995) say that the management of a firm manipulate revenue rather than expenses. In light of the said, the model used in this paper for predicting earnings management was re-estimated by incorporating the performance (OPF) measures, as shown in equation 2 :
$O P F=\frac{R E V(N I-C F O)+T A(E B I T-C F O)}{T A(R E V)}$

Given equations 1 and 2, equations 3-6 were specified so as to validate the relevant hypotheses of the study. The OPF denotes performance (return on assets and return on equity).

Earnings Management and Return on Assets (ROA)

$R O A=f\left\{\frac{R E V(N I-C F O)+T A(E B I T-C F O)}{T A(R E V)}\right\}(3)$

Earnings Management and Return on Equity (ROE)

$R O E=f\left\{\frac{R E V(N I-C F O)+T A(E B I T-C F O)}{T A(R E V)}\right\}$

In light of the equations 3-4, equations 5-6 are expressed in an explicit form and represented as equations 5-6:

$$
\begin{aligned}
& R O A_{i t}=\alpha_{0}+\beta_{1} E M T_{i t}+\varepsilon_{i t} \\
& R O E_{i t}=\alpha_{0}+\beta_{1} E M T_{i t}+\varepsilon_{i t}
\end{aligned}
$$

where $i$ represents the $i^{\text {th }}$ observation of the dependent and independent variables; $t$ denotes the timeframe; $\alpha_{0}$ represents an intercept; $\beta_{1}$ denotes the slope coefficient; $\varepsilon$ is the residual (the error term) for the ith observation.

In order to control for the relationship between the dependent and the independent variables, the characteristics of the firms (the size of the firm gauged by the total asset logarithm) was introduced, which, according to TAD, offers management flexible opportunities to experiment or transform accounting figures. Likewise, a change in the earnings before interest and taxes $(\triangle E B I T)$ and the percentage change in the net profit after tax $(\triangle N P A T)$ were introduced as the control variables, resulting in equations 7-8. $\triangle E B I T$ and $\triangle N P A T$ were initiated as suggested by $\mathrm{M}$. Riley (2007); G. Gong et al (2008) and J. D. Gramlich and O. V. Sorensen (2010), who say that they can be employed to correct the error forecasts made by the 
management, linked with the accounting figures. The aggregated earnings management models are presented in equations 7-8:

$$
\begin{aligned}
& R O A_{i t}=\alpha_{0}+\beta_{1} E M T_{i t}+\beta_{2} F_{S I Z E_{i t}}+ \\
& \beta_{3} \Delta E B I T_{i t}+\beta_{4} \Delta N P A T_{i t}+\varepsilon_{i t} \\
& R O E_{i t}=\alpha_{0}+\beta_{1} E M T_{i t}+\beta_{2} F S I Z E_{i t}+ \\
& \beta_{3} \Delta E B I T_{i t}+\beta_{4} \Delta N P A T_{i t}+\varepsilon_{i t}
\end{aligned}
$$

The study covers the period from 2012 to 2018 for the selected publicly quoted firms in Sub-Saharan Africa. The analysis of the data specifically encompass descriptive statistical tools (the mean, the standard deviation, the minimum and maximum values and the correlation matrix) and inferential statistical tools (the OLS, fixed and random effects, and the Hausman specification test). The analysis was done with the help of the STATA 13.0 version.

\section{RESULTS}

In Table 1, the descriptive results are presented, particularly the mean, the standard deviation, the minimum and maximum values of the analysed variables for Sub-Saharan Africa. The mean earnings management (EMT) score included was 20.0658, with the minimum and maximum EMT scores of -315.4260 and 422.4490 , respectively. Similarly, return on equity $(R O E)$, return on assets $(R O A)$, the size of the firm (FSIZE), a change in the earnings before interest and taxes $(\triangle E B I T)$ and a change in the net profit after tax $(\triangle N P A T)$ had the mean scores of 44.9141, 19.3859, $46.1513,0.8410$ and -10.5011 , respectively.

In addition, the standard deviation values for South Africa (25.8755), West Africa (22.1158) and East Africa (15.3964) supports the reasons why earnings management is predominant among Sub-Saharan African firms, particularly so South Africa (South Africa) and West Africa (Nigeria). Overall, there is a symptomatic significant difference between the mean

Table 1 The descriptive results of the analyzed variables for Sub-Saharan Africa

\begin{tabular}{l|cccccc}
\hline Countries & EMT & ROE & ROA & FSIZE & $\Delta E B I T$ & $\Delta N P A T$ \\
\hline Mean (Nigeria) & 7.0009 & 15.6704 & 6.7637 & 16.1021 & 0.2934 & -3.6638 \\
Mean (South Africa) & 8.1911 & 18.3344 & 7.9135 & 18.8394 & 0.3433 & -4.2867 \\
Mean (Kenya) & 4.8738 & 10.9093 & 4.7087 & 11.2098 & 0.2043 & -2.5506 \\
\hline Grand Total & 20.0658 & 44.9141 & 19.3859 & 46.1513 & 0.8410 & -10.5011 \\
\hline Std. Dev. (Nigeria) & 22.1158 & 104.0443 & 11.1076 & 104.0440 & 1.7094 & 53.2526 \\
Std. Dev. (South Africa) & 25.8755 & 121.7318 & 12.9959 & 121.7315 & 1.9999 & 62.3055 \\
Std. Dev. (Kenya) & 15.3964 & 72.4325 & 7.7328 & 72.4323 & 1.1900 & 37.0729 \\
\hline Grand Total & 63.3877 & 298.2086 & 31.8363 & 298.2078 & 4.8993 & 152.631 \\
\hline Min. Val. (Nigeria) & -114.0300 & -989.3800 & -31.6000 & -77.3800 & -16.7928 & -847.5000 \\
Min. Val. (South Africa) & -122.0120 & -1058.6400 & -33.8120 & -82.7966 & -17.9683 & -906.8250 \\
Min. Val. (Kenya) & -79.3843 & -688.7770 & -21.9990 & -53.8696 & -11.6906 & -590.0040 \\
\hline Grand Total & -315.4260 & -2736.8000 & -87.4110 & -214.0460 & -46.4517 & -2344.3290 \\
\hline Max. Val. (Nigeria) & 162.7200 & 1131.0100 & 61.8700 & 143.0000 & 15.4860 & 43.6451 \\
Max. Val. (South Africa) & 146.4482 & 1097.9100 & 55.6831 & 128.7001 & 13.9374 & 39.2806 \\
Max. Val. (Kenya) & 113.2808 & 787.3752 & 43.0720 & 99.5523 & 10.7809 & 30.3844 \\
\hline Grand Total & 422.4490 & 3016.2950 & 160.6251 & 371.2524 & 40.2043 & 113.3101 \\
\hline
\end{tabular}

Source: Authors 
and the standard deviation, which implies significant dissimilarities in earnings management and the performance attributes of Sub-Saharan Africa, which may be a good indicator for assessing the extent to which earnings management may exert significant pressure on the performance measures of the study.

Table 2 accounts for the correlation matrix of the summarized variables. The correlation matrix of the summarized variables reveals that the performance variables (ROE and $R O A$ ) are positively correlated to EMT, FSIZE, $\triangle E B I T$ and $\triangle N P A T$. According to D. N. Gujarati (2003), when the coefficient of two pairs of explanatory variables exceeds the value 0.8 , then multicollinearity is present.

Given the foregoing results, not a single correlation coefficient of the explanatory variables exceeds 0.8. Consequently, the study concludes that there is no multicollinearity at all among the pairs of the explanatory variables. Impliedly, the earnings management, performance and control variables of the study are suitable for estimating a regression model.

The Shapiro-Wilk W data normality test is presented in Table 3, and the values W are the Shapiro-Wilk test statistics. S. S. Shapiro and M. B. Wilk (1965), and S. S. Shapiro and R. S. Francia (1972) suggest that the large values of $\mathrm{V}$ show the non-normality of data. However, the $\mathrm{V}$ values are small and fall within a range from 1.9 to 1.1, thus indicating the normality of the data. More so, the Prob. $Z$ values provide sufficient evidence to accept the hypotheses that ROE, ROA, EMT, FSIZE, $\triangle E B I T$ and $\triangle N P A T$ are normally distributed.

In Table 4 the results of the OLS, the fixed and random effects of the entire panel data for Sub-Saharan Africa are presented. The result of the testing of the suitability of the models (the ordinary least square OLS; the fixed effect - FE and the random effect - RE) show that the RE is more efficient than the FE, as is indicated in the result of the Hausman specification test of Chi2(3) $=0.34$, $p$-value $=0.9529$. The OLS model

Table 2 The correlation matrix of the Summarized Variables

\begin{tabular}{l|cccccc}
\hline Variable & ROE & ROA & EMT & FSIZE & $\Delta$ EBIT & $\Delta N P A T$ \\
\hline ROE & 1.0000 & & & & & \\
ROA & 0.4680 & 1.0000 & & & & \\
EMT & 0.0487 & 0.0512 & 1.0000 & & & \\
FSIZE & 0.0398 & 0.0234 & 0.2008 & 1.0000 & & \\
$\Delta E B I T$ & 0.0706 & 0.0552 & 0.0470 & -0.0274 & 1.0000 & \\
$\Delta$ NPAT & 0.0384 & -00015 & 0.0132 & 0.0326 & 0.0671 & 1.0000 \\
\hline
\end{tabular}

Source: Authors

Table 3 The Shapiro-Wilk W data normality test

\begin{tabular}{l|ccccc}
\hline Variable & Obs. & W & V & Z & Prob. $>$ Z \\
\hline ROE & 612 & 0.9528 & 1.9126 & 0.8310 & 0.9086 \\
ROA & 612 & 0.9839 & 1.3454 & 0.6401 & 0.2634 \\
EMT & 612 & 0.9533 & 1.7082 & 0.7134 & 0.9055 \\
FSIZE & 612 & 0.9892 & 1.1113 & 0.1959 & 0.4247 \\
$\Delta$ EBIT & 612 & 0.9246 & 1.4449 & 1.1254 & 0.8434 \\
$\Delta$ NPAT & 612 & 0.9640 & 1.9915 & 1.4419 & 0.2573 \\
\hline
\end{tabular}

Source: Authors 
Table 4 The OLS and the fixed and random effects of the summarized variables for Sub-Saharan Africa

\begin{tabular}{|c|c|c|c|c|c|c|}
\hline \multirow{2}{*}{$\begin{array}{l}\text { Dependent Variable: } \\
\text { Variable }\end{array}$} & \multirow{2}{*}{$\begin{array}{l}\text { ROA } \\
\text { Coef. }\end{array}$} & \multirow{2}{*}{$\begin{array}{l}\text { OLS } \\
\text { Prob. }\end{array}$} & \multicolumn{2}{|c|}{ FE } & \multicolumn{2}{|l|}{$R E$} \\
\hline & & & Coef. & Prob. & Coef. & Prob. \\
\hline EMT & $\begin{array}{l}0.4463^{*} \\
(18.48)\end{array}$ & 0.000 & $\begin{array}{l}0.4640 * \\
(18.31)\end{array}$ & 0.000 & $\begin{array}{l}0.4463^{*} \\
(18.48)\end{array}$ & 0.000 \\
\hline FSIZE & $\begin{array}{c}0.4035^{*} \\
(16.71)\end{array}$ & 0.000 & $\begin{array}{l}0.4195^{*} \\
(16.55)\end{array}$ & 0.000 & $\begin{array}{c}0.4035^{*} \\
(16.71)\end{array}$ & 0.000 \\
\hline$\triangle E B I T$ & $\begin{array}{l}0.1823 \\
(0.71)\end{array}$ & 0.477 & $\begin{array}{l}0.1966 \\
(0.76)\end{array}$ & 0.448 & $\begin{array}{l}0.1823 \\
(0.71)\end{array}$ & 0.477 \\
\hline$\triangle N P A T$ & $\begin{array}{l}0.0780 \\
(0.98)\end{array}$ & 0.330 & $\begin{array}{l}0.0072 \\
(0.89)\end{array}$ & 0.375 & $\begin{array}{l}0.0078 \\
(0.98)\end{array}$ & 0.329 \\
\hline R-Squared & 0.5910 & & & & & \\
\hline R-Squared Adj. & 0.5859 & & & & & \\
\hline Prob. F. & 0.0000 & & & & & \\
\hline R-Squared (within) & & & 0.5900 & & 0.5900 & \\
\hline R-Squared (between) & & & 0.8010 & & 0.8073 & \\
\hline R-Squared (overall) & & & 0.5910 & & 0.5190 & \\
\hline Wald Ch2 & & & & & 345.38 & \\
\hline Prob. Ch2 & & & & & $0.000 *$ & \\
\hline Hausman Test & & & $\operatorname{Chi2}(2)=0.34$ & & Prob $>$ Chi $2=0.9529$ & \\
\hline
\end{tabular}

Note: *significant at 1\%; **significant at 5\%; the items in parentheses are the t-values; $F=115.13$

Source: Authors

indicates that the EMT has a larger beta coefficient in absolute terms than the other variables (FSIZE, $\triangle E B I T$ and $\triangle N P A T)$ do.

Even more so, when the firms in Sub-Saharan Africa engage themselves in earnings management, such an engagement results in an approximately 44.6 percent change in the level of performance $(R O A)$, and $40.4 \%, 18.2 \%$ and $7.8 \%$ change in the FSIZE, $\triangle E B I T$ and $\triangle N P A T$, respectively. The Wald Ch2-statistics are 345.38 , with a p-value 0.000 , supporting the hypothesis that earnings management (EMT) exerts significant pressure on the return on assets $(R O A)$ of the firms operating in Sub-Saharan Africa.

The results of the OLS and the fixed and random effects of the entire panel data for Sub-Saharan Africa are presented in Table 5. The results reveal the fact that $R E$ is more efficient than $F E$, as is shown in the
Hausman specification test result of Chi2 (3) $=0.44$, p-value $=0.9311$. The OLS model indicates that EMT has a greater beta coefficient in absolute terms than the other variables (FSIZE, $\triangle E B I T$ and $\triangle N P A T$ ) do. Furthermore, the Wald Ch2-statistics are 8.88, with a p-value 0.0309 , thus supporting the hypothesis that earnings management (EMT) exerts significant pressure on firms return on equity (ROE) in SubSaharan Africa

\section{DISCUSSION}

In the paper, whether earnings management exerts significant pressure on firms' returns on assets and equity in Sub-Saharan Africa is investigated. Particularly, the findings follow the a priori expectation: first, the study finds that the 
Table 5 The LS and the fixed and random effects of the summarized variables for Sub-Saharan Africa

\begin{tabular}{|c|c|c|c|c|c|c|}
\hline \multirow{2}{*}{$\begin{array}{l}\text { Dependent Variable: } \\
\text { Variable }\end{array}$} & \multirow{2}{*}{$\begin{array}{l}\text { ROE } \\
\text { Coef. }\end{array}$} & \multirow{2}{*}{$\begin{array}{l}\text { OLS } \\
\text { Prob. }\end{array}$} & \multicolumn{2}{|c|}{$\mathrm{FE}$} & \multicolumn{2}{|c|}{$R E$} \\
\hline & & & Coef. & Prob. & Coef. & Prob. \\
\hline EMT & $\begin{array}{c}0.7950^{*} \\
(2.88)\end{array}$ & 0.004 & $\begin{array}{c}0.7918^{*} \\
(2.84)\end{array}$ & 0.005 & $\begin{array}{c}0.7950 * \\
(2.88)\end{array}$ & 0.004 \\
\hline FSIZE & $\begin{array}{c}0.7187^{*} \\
(2.60)\end{array}$ & 0.004 & $\begin{array}{c}0.7158^{*} \\
(2.57)\end{array}$ & 0.005 & $\begin{array}{c}0.7187^{*} \\
(2.60)\end{array}$ & 0.004 \\
\hline$\triangle E B I T$ & $\begin{array}{l}1.7199 \\
(0.59)\end{array}$ & 0.558 & $\begin{array}{l}0.1851 \\
(0.63)\end{array}$ & 0.533 & $\begin{array}{l}1.7199 \\
(0.59)\end{array}$ & 0.557 \\
\hline$\triangle N P A T$ & $\begin{array}{l}0.0209 \\
(0.23)\end{array}$ & 0.820 & $\begin{array}{l}0.0120 \\
(0.13)\end{array}$ & 0.897 & $\begin{array}{c}0.0209 \\
(0.23)\end{array}$ & 0.820 \\
\hline R-Squared & 0.0358 & & & & & \\
\hline R-Squared Adj. & 0.0237 & & & & & \\
\hline Prob. F. & 0.0329 & & & & & \\
\hline R-Squared (within) & & & 0.0357 & & 0.0357 & \\
\hline R-Squared (between) & & & 0.0578 & & 0.0986 & \\
\hline R-Squared (overall) & & & 0.0358 & & 0.0358 & \\
\hline Wald Ch2 & & & & & 8.88 & \\
\hline Prob. Ch2 & & & & & $0.0309^{*}$ & \\
\hline Hausman Test & & & Chi2 & & Prob $>C$ & 9311 \\
\hline
\end{tabular}

Note: *significant at $1 \%$; **5\%; the items in parentheses are the t-ratios; the Z-test in parentheses bold face; $F=2.96$

Source: Authors

performance variables (ROA and $R O E)$ are positively correlated with EMT, FSIZE, $\triangle E B I T$ and $\triangle N P A T$, thus clearly indicating the fact that the developed earnings management prediction models positively show relationships with the performance variables of the study. Again, the normality test results provide adequate evidence for us to accept that earnings management $(E M T)$, the performance variables ( $R O E$ and $R O E$ ) and the control variables (FSIZE, $\triangle E B I T$ and $\triangle N P A T)$ are normally distributed.

Moreover, the result of the random effect implies that the firms from which the measurements were drawn are not fixed and the variations between the firms in Sub-Saharan Africa may be of interest are perhaps one of the reasons why earnings management may be predominant in the other regions of Sub-Saharan Africa. Furthermore, the t-test result suggests that $\triangle E B I T$ and $\triangle N P A T$ do not account for the management error forecast linked with accounting figures, as is suggested by G. Gong et al (2008) and J. D. Gramlich and O. V. Sorensen (2010), but rather that the size of a firm largely explains changes in the level of performance.

Overall, this study has established the fact that earnings management exerts significant pressure on firms' performances. The results obtained herein are in part similar to the findings of prior studies on earnings management (Gong et al, 2008; Dechow, Hutton, Kim \& Sloan, 2012; Dobre et al, 2015; Gnyana, 2016) that find the significant evidence of a significant positive relationship between earnings management and the performance variables of firms, thus implying an impartial application of the accounting principles, rather than the proactive choices of accounting methods made by management. 
First, this study contributes to the accounting literature by reaffirming the position of prior studies on earnings management; second, this study contributes to the accounting literature in that it indicates the fact that, notwithstanding the fact that earnings management does exert significant pressure on firms' return on assets and equity, earnings management is high in South Africa, only to be followed by West Africa, and low in East Africa. Finally, this study contributes to knowledge, indicating the fact that the size of a firm plays a vital role in moderating the relationship between the earnings management and performance (return on assets and return on equity) of Sub-Saharan African firms. This may explain one of the rationales for the predominance of the use of earnings management among Sub-Saharan African firms, particularly those operating in South Africa (South Africa) and West Africa (Nigeria).

\section{CONCLUSION}

Within the milieu of the proposed earnings management model for Sub-Saharan Africa, it is discerned that it is not only earnings management that exerts significant pressure on the $\mathrm{ROA} / \mathrm{ROE}$ of the firms operating in Sub-Saharan Africa, but the practice of earnings management conducted in these publicly quoted industrial/consumer goods firms in South Africa (South Africa) and Nigeria (West Africa) is also high, whereas that practice is low in Kenya (East Africa), which shows that the West African and South African nations are yet to fully comply with the global accounting principles and standards. Consequently, the South African and West African nations should consider encouraging firms to fully comply with the global principles and standards in order for the magnitude of earnings management to decrease.

The Wald Ch2-statistics for both models indicates the fact that earnings management exerts significant and positive pressure on the returns on asset and returns on equity of the publicly quoted industrial/ consumer goods firms in Sub-Saharan Africa, which, however, is also partly due to the size of the firms. Thus, the national agency of each nation should offer a more specific accounting guideline on the requirement for and the extent of earnings management practice to be conducted by the publicly quoted industrial/ consumer goods firms and by those quoted in the other sectors so as to ensure the transparency of the capital market and the albeit wrong practice of earnings management by firms in Sub-Saharan Africa.

Furthermore, the research has several limitations in terms of the sector covered and the extension of the study in order for it to cover the other regions of SubSaharan Africa. Consequently, future studies should consider investigating the other sectors as well and extend such investigations to the other regions of Sub-Saharan Africa. In fact, the model proposed in this study can be tested in the other regions of SubSahara Africa. These limitations further open the questions as to whether earnings management may exert significant pressure on firms in the other sectors and regions of Sub-Saharan Africa.

\section{REFERENCES}

Abdoli, M., Bakhtiarnezhad, S., \& Bakshi, H. (2012). Effect of discretionary accruals and corporate size on auditor's opinion. African Journal of Business Management, 6(10), 38293833. doi:10.5897/AJBM11.2676

Ali, M. A., Ismael, H. R., \& Ahmed, A. H. (2020). Equity incentives, earnings management and corporate governance: Empirical evidence using UK panel data. Corporate Ownership \& Control, 17(2), 104-123. doi.org/10.22495/cocv17i2art10

Augustia, D., Muhammad, N. P., \& Permatasari, Y. (2020). Earnings management, business strategy, and bankruptcy risk: Evidence from Indonesia. The Authors, Published online, Elsevier Ltd.

Ayers, B. C., Jiang, J. X., \& Yeung, P. E. (2006). Discretionary accruals and earnings management: An analysis of pseudo earnings targets. The Accounting Review, 81(3), 617-652. doi.org/10.2308/accr.2006.81.3.617 
Ball, R., \& Shivakumar, L. (2006). The role of accruals in asymmetrically timely gain and loss recognition. Journal of Accounting Research, 44(2), 207-242. doi.org/10.1111/j.1475679X.2006.00198.x

Barth, M. E. (2010). Perspectives in accounting alchemy. BIS Working Papers.

Barth, M. E., Landsman, W. R., \& Lang, M. H. (2008). International accounting standards and accounting quality. Journal of Accounting Research, 46(3), 467-498. doi.org/10.1111/ j.1475-679X.2008.00287.x

Bartov, E., Gul, F. A., \& Tsui, J. S. L. (2000). Discretionary accruals models and audit qualifications. Journal of Accountability and Economics, 30(3), 421-452. doi:10.1016/ S0165-4101(01)00015-5

Boghdady, A. B. A. (2019). Accrual and real earnings management in both state-owned and privately-owned Egyptian companies. Corporate Ownership \& Control, 17(1), 8-13. doi.org/10.22495/cocv17ilart1

Burgstahler, D., \& Dichev, I. (1997). Earnings management to avoid earnings decreases and losses. Journal of Accounting and Economics, 24(1), 99-126. doi.org/10.1016/S01654101(97)00017-7

Cole, C. R. (2017). Volatility and the alchemy of risk: Reflexivity in the shadows of black Monday. A publication of ARTEMS capital management.

Dechow, P. M., Sloan, R., \& Sweeney, A. (1995). Detecting earnings management. The Accounting Review, 70(2), 193225 .

Dechow, P. M., Hutton, A., Kim, J. H., \& Sloan, R. G. (2012). Detecting earnings management: A new approach. Journal of Accounting Research, 50(2), 275-334. doi.org/10.1111/j.1475679X.2012.00449.x

DeFond, M. L., \& Jiambalvo, J. (1994). Debt covenant effects and the manipulation of accruals. Journal of Accounting and Economics, 17(1-2), 145-176. doi.org/10.1016/01654101(94)90008-6

Dobre, F., Brad, L., \& Ciobanu, R. (2015). The value of discretionary accruals computed using both national and international standards. Accounting and Management Information System, 14(1), 153-169.

Elshafie, E., \& Nyadroh, E. (2014). Are discretionary accruals a good measure of audit quality? Journal of Management Policy and Practice, 15(2), 43-59.
Gaver, J., Gaver, K., \& Austin, J. (1995). Additional evidence on bonus plans and income management. Journal of Accounting and Economics, 19(1), 3-28. doi:10.1016/0165-4101(94)00358-C

Gnyana, R. B. (2016). Discretionary accruals and earnings management by oil companies in India. Indian Journal of Accounting, 48(2), 32-36.

Gong, G., Li, H., \& Xie, H. (2009). The association between management earnings forecast errors and accruals. The Accounting Review, 84(2), 497-530. doi.org/10.2308/ accr.2009.84.2.497

Gramlich, J. D., \& Sorensen, O. V. (2010). Voluntary management earnings forecasts and discretionary accruals: evidence from Danish IPOs. European Accounting Review, 13(2), 235-259. doi.org/10.1080/0963818042000203338

Grimaldi, F. (2019). The relationship between financial crisis and earnings management: Some evidence from the Italian context. Corporate Ownership \& Control, 17(1), 325-335. doi.org/10.22495/cocv17i1siart13

Gujarati, D. N. (2003). Basic econometrics. New York, NY: McGraw-Hill Inc.

Hagerman, R. L., \& Zmijewski, M. E. (1979). Some economic determinants of accounting policy choice. Journal of Accounting \& Economics, 1(2), 141-161.

Hunjra, A. I., Perveen, U., Li, L., Chani, M. I., \& Mehmood, R. (2020). Impact of ownership concentration, institutional ownership and earnings management on stock market liquidity. Corporate Ownership \& Control, 17(2), 77-87. doi.org/10.22495/cocv17i2art7

Johannesburg Stock Exchange (JSE). Listed companies. Retrieved March 4, 2019, from https://www.african-markets. com/en/stock-markets/jse/listed-companies

Jones, J. (1991). Earnings management during import relief investigations. Journal of Accounting Research, 29(2), 193-228. doi.org/10.2307/2491047

Kothari, S. P., Leone, A., \& Wasley, C. (2005). Performance matched discretionary accruals measures. Journal of Accounting and Economics, 39(1), 163-197. doi.org/10.1016/j. jacceco.2004.11.002

Lennox, C., \& Park, C. (2006). The informativeness of earnings and management's issuance of earnings forecasts. Journal of Accounting and Economics, 42(3), 439-458. doi:10.1016/j. jacceco.2006.05.001 
Moradzadehfard, M., \& Nazari, H. (2013). Evaluation of management earnings forecast error and information content of accruals: listed companies in Tehran stock exchange. Journal of Education and Vocational Research, 4(4), 119-129. doi.org/10.22610/jevr.v4i4.109

Nachmias, F., \& Nachmias, D. (2009). Research methods in the social science. London, UK: Taylor \& Francis Ltd.

Nairobi Securities Exchange (NSE). Listed companies. Retrieved March 4, 2019, from https://www.african-markets.com/en/ stock-markets/nse/listed-companies

Nigerian Stock Exchange. (2018). Listed companies. Retrieved March 4, 2019, from http://www.nse.com.ng/Listings-site/ listed-securities/listed-companies

Rangan, S. (1998). Earnings management and the performance of seasoned equity offerings. Journal of Financial Economics, 50(1), 101-122. doi.org/10.1016/S0304-405X(98)00033-6

Riley, M. (2007). Accounting information and analyst forecast errors: A study of the explanatory power of discretionary accruals and accruals quality. A Dissertation Submitted to the Graduate Faculty of Texas Tech University in Partial Fulfillment of the Requirements for the Degree of Doctor of Philosophy.

Shapiro, S. S., \& Wilk, M. B. (1965). An analysis of variance test for normality (complete samples). Biometrika, 52(3/4), 591-611. doi.org/10.2307/2333709
Shapiro, S. S., \& Francia, R. S. (1972). An approximate analysis of variance test for normality. Journal of the American Statistical Association, 67(337), 215-216. doi.org/10.1080/01621 459.1972.10481232

Teoh, S. H., Welch, I., \& Wong, T. J. (1998). Earnings management and the underperformance of seasoned equity offerings. Journal of Financial Economics, 50(1), 63-99. doi.org/10.1016/S0304-405X(98)00032-4

Thenmozhi, M., Saravanan, P., \& Sasidharan, A. (2019). Impact of excess cash on earnings management and firm value: Evidence from China. Corporate Ownership \& Control, 17(1), 245-254. doi.org/10.22495/cocv17i1siart7

Verrecchia, R. E. (2009). Accounting alchemy and financial system behavior. BIS Working Papers, No. 302.

Watts, R. L., \& Zimmerman, J. L. (1986). Positive accounting theory. Prentice Hall, Englewood Cliffs, $\mathrm{Nj}$.

Zunera, K., Farah, Y., \& Muhammad, M. A. (2015). The pricing of discretionary accruals - Evidence from Pakistan. Journal of Management and Research, 2(2), 1-22. doi.org/10.29145/ jmr/22/0202002

\section{Received on $22^{\text {nd }}$ September 2020, after revision, accepted for publication on $18^{\text {th }}$ December 2020. Published online on $25^{\text {th }}$ December 2020.}

Edesiri Godsday Okoro, Ph.D, is a lecturer at Delta State University, Abraka, Nigeria. He received his Ph.D. at the Department of Accountancy of the Faculty of Management Sciences, Nnamdi Azikiwe University, Awka, Anambra State, Nigeria. His field of study is accounting, with research interests in corporate reporting, accounting theory, earnings management and financial management.

Confidence Joel Ihenyen, Ph.D., is a senior lecturer at the Department of Accounting/ Finance of the Faculty of Management Sciences, Niger Delta University, Amassoma, Bayelsa State, Nigeria. His field of study is accounting, with research interests in management accounting and corporate reporting. 


\title{
DA LI UPRAVLJANJE ZARADAMA VRŠI PRITISAK NA PRINOS NA UKUPNU IMOVINU I KAPITAL PREDUZEĆA? STUDIJA SLUČAJA PODSAHARSKE AFRIKE
}

\author{
Edesiri Godsday Okoro ${ }^{1}$ i Confidence Joel Ihenyen ${ }^{2}$
}

${ }^{1}$ Department of Accounting and Finance, Faculty of the Social Sciences, Delta State University, Nigeria

${ }^{2}$ Department of Accounting/Finance, Faculty of Management Sciences, Niger Delta University, Nigeria

Uprkos stanovištima izloženim u prethodnim studijama, koje su se bavile pitanjem upravljanja zaradama, nije urađena nijedna studija u kojoj bi se istraživala pitanja da li upravljanje zaradama vrši pritisak na prinos na ukupnu imovinu i kapital preduzeća, a naročito ne postoji nijedna studija koja bi se tim pitanjem bavila u kontekstu Podsaharske Afrike. Izvodeći zaključke iz postojećih modela za upravljanje zaradama, u ovom radu je razvijen jedan drugačiji model upravljanja zaradama, koji se razlikuje od modela korišćenih u ranijim studijama, a koji se, možda, uklapa u specifičnosti miljea Podsaharske Afrike. Podaci su pribavljeni iz baze podataka Berze zemalja Podsaharske Afrike, upotrebom statističke tehnike stalnih i nasumičnih efekata. Koristeći predloženi model za upravljanje zaradama, studija dolazi do intrigantnih rezultata, koji, moguće je, doprinose saznanjima i daju svoj doprinos literaturi, bez obzira na činjenicu da upravljanje zaradama vrši značajan pritisak na performanse preduzeća. Štaviše, upravljanju zaradama se pridaje veliki značaj u Južnoj i Zapadnoj Africi, dok mu se mali značaj pridaje u Istočnoj Africi. Zanimljivo je to što se u studiji došlo do saznanja o tome da veličina preduzeća igra vitalnu ulogu u posredovanju u vezi između upravljanja zaradama i performansi preduzeća koja posluju u Podsaharskoj Africi.

Ključne reči: upravljanje zaradama, prinos na ukupnu imovinu, prinos na kapital, finansijski izveštaji, Podsaharska Afrika 